\title{
Use of Two Sulfonphthalein Dyes for the Sensitive and Selective Extraction-Free Spectrophotometric Assay of Albendazole in Bulk Drug and in Tablets
}

\author{
Nagaraju Swamy and Kanakapura Basavaiah \\ Department of Chemistry, University of Mysore, Mysore, Karnataka 570 006, India \\ Correspondence should be addressed to Kanakapura Basavaiah; basavaiahk@yahoo.co.in
}

Received 20 April 2013; Accepted 14 May 2013

Academic Editors: A. Bouklouze and A. Przyjazny

Copyright (C) 2013 N. Swamy and K. Basavaiah. This is an open access article distributed under the Creative Commons Attribution License, which permits unrestricted use, distribution, and reproduction in any medium, provided the original work is properly cited.

\begin{abstract}
Albendazole (ALB) is a potent benzimidazole anthelmintic used in the treatment of human intestinal helmintiasis as well as of hytatid cysts and neurocysticercosis. Two rapid, simple, sensitive, and selective spectrophotometric methods are presented for the determination of ALB in pharmaceuticals. The methods are based on the formation of dichloromethane soluble 1:1 ion-pair complexes (ALB : dye) formed between ALB and sulfonphthalein dyes, bromophenol blue BPB, (method A) and bromothymol blue BTB, (method B). The complexes formed were measured directly (without extraction) at $445 \mathrm{~nm}$ (method A) and $460 \mathrm{~nm}$ (method B). The experimental conditions were optimized and the systems obey Beer's law for 1.5-21.0 and 2.0-32.0 $\mu \mathrm{g} \mathrm{mL} \mathrm{LLB}^{-1} \mathrm{ALor}_{\mathrm{method}}$ A and method B respectively. The molar absorptivity and Sandell's sensitivity were calculated to be $1.27 \times 10^{4} \mathrm{~L} \mathrm{~mol}^{-1} \mathrm{~cm}^{-1}$ and $0.0209 \mathrm{ng} \mathrm{cm}^{-2}$, and $7.57 \times 10^{3} \mathrm{~L} \mathrm{~mol}^{-1} \mathrm{~cm}^{-1}$ and $0.0350 \mathrm{ng} \mathrm{cm}^{-2}$ using BPB and BTB, respectively. The limits of detection and quantification were calculated to be 0.01 and 0.03 , and 0.16 , and $0.49 \mu \mathrm{g} \mathrm{mL}^{-1}$ using BPB and BTB, respectively. The relative standard values for intra-day and inter-day precision were less than $3 \%$, and the accuracy was better than $3 \%$ for both methods.
\end{abstract}

\section{Introduction}

Albendazole (ALB), chemically known as methyl-5-(propyl thio)-2-yl benzimidazole methyl carbamate [1], is widely used as an anthelmintic having a wide spectrum of activity [2]. The drug is official in British Pharmacopoeia [3], which describes a potentiometric titration with perchloric acid in formic acidacetic acid medium. Quantitative determination of ALB in dosage forms has received wide attention and several methods have been reported and include titrimetry in nonaqueous medium $[4,5]$, redox titrimetry [6-12], UV spectrophotometry [13-17], spectrofluorimetry [18,19], voltammetry [20-22], high performance liquid chromatography [23-27], and high performance thin layer chromatography $[28,29]$.

Several visible spectrophotometric methods, both direct and indirect, are found in the literature for the determination of ALB in pharmaceuticals. Basavaiah et al. [30] in their methods treated ALB with a known excess of NBS in $\mathrm{HCl}$ medium, and the unreacted oxidant was reduced by iron(II) and the resulting iron(III) was complexed with thiocyanate or tiron offering two sensitive methods. Two more indirect methods [31] involving NBS-metol-sulfanilamide and NBScelesteine blue as chromogenic systems have been proposed by Sastry et al. Several other reaction schemes involving chloramine-T-methyl orange or indigocarmine [6], chloramineT-metol-sulfanilic acid [7], NBS-methyl orange or indigocarmine [10], N-chlorosuccinimide-iron(II)-thiocyanate [11], $\mathrm{NaIO}_{4}-\mathrm{KBr}$-methyl orange or indigocarmine [12], and perchloric acid-crystal violet [4] are also found in the literature for the indirect spectrophotometric assay of ALB in its dosage forms.

Only a few direct spectrophotometric methods are reported for ALB. Zarapkar and Deshpande [32] have determined the drug in tablets and syrups based on the reduction of Folin-Ciocalteu reagent to a blue coloured chromogen which was measured at $700 \mathrm{~nm}$. The charge-transfer reaction 
of ALB with $\pi$-acceptor chloranilic acid in alcoholic acetone medium was used by Zhao et al. [33] for the determination of the drug in tablets. Based on similar reaction and employing chloranilic acid and 2,3-dichloro-5,6-dicyanop-benzoquinone (DDQ) as $\pi$-acceptors, determination of ALB in tablets has been reported by Refat et al. [34]. Ionpair reaction involving ALB and acidic dyes has been the basis of extractive spectrophotometric assay of ALB [3537]. Sane et al. [35] have described four procedures based on this reaction using bromocresol green, bromophenol blue, bromothymol blue, and bromophenol red as ion-pair reagents in acidic buffer medium. The ion-pair complexes formed were extracted into chloroform and measured at $420 \mathrm{~nm}$. The methods were applied to tablets and syrup. Thymol blue and six alizarin derivatives [36] are the other ion-pair reagents used for the assay of ALB. Sastry et al. [37] have devised extractive spectrophotometric methods for the estimation of some benzimidazole anthelmintics including ALB in pharmaceuticals based on ion-pair reaction and employing some acidic dyes.

All the indirect spectrophotometric methods cited above $[4,6,7,10-12,30,31]$ are cumbersome involving multireagents and multistep reactions and, hence prone to inaccuracy and imprecision. On the other hand, the reported direct spectrophotometric methods $[33,34]$ are less sensitive with the molar absorptivity value being $<1 \times 10^{4} \mathrm{~L} \mathrm{~mol}^{-1} \mathrm{~cm}^{-1}$. The methods based on ion-pair reaction [35-37], though sensitive, involve tedious and time consuming extraction step besides being critically dependent on $\mathrm{pH}$ of the aqueous phase and the aqueous-organic phases ratio. Additionally, incomplete extraction of the analyte may lead to erratic results. In an attempt to overcome these shortcomings associated with extractive spectrophotometric methods, several workers in recent years have devised extraction-free spectrophotometric methods for several pharmaceutical substances [38-45] based on ion-pair reaction and employing some sulfonphthalein dyes. These new procedures are free from critical $\mathrm{pH}$ adjustment and laborious liquid-liquid extraction step and involve simple mixing the drug and dye solutions in organic solvent and measuring the absorbance of the resulting ion-pair complex at wavelength of maximum absorption.

The present work presents two simple, rapid, sensitive, and selective spectrophotometric methods for ALB based on ion-pair reaction and using bromophenol blue (BPB) and bromothymol blue (BTB) as ion pair reagents. The striking feature of these methods is the absence of the extraction step, and the methods are absolutely free from critical experimental variables, unlike the direct and indirect spectrophotometric methods cited earlier. They were demonstrated to be highly precise and accurate besides being robust and rugged.

\section{Experimental}

2.1. Apparatus. A Systronics model 166 digital spectrophotometer (Systronics, Ahmedabad, Gujarat, India) equipped with $1 \mathrm{~cm}$ matched quartz cells was used for all absorbance measurements.

2.2. Materials. Pharmaceutical grade ALB (99.7 percent pure) was received as a gift from Cipla India, Ltd., Mumbai, India and used as received. Alworm-400 (Medopharm Ltd., Malur, India), ABD-400 (Intas Pharmaceuticals, Ltd., Ahmedabad, India,) and Bandy-400 (Mankind Pharmaceuticals, Ltd., New Delhi, India) tablets were purchased from local commercial sources.

2.3. Reagents and Chemicals. All reagents used were of analytical reagent grade, and HPLC grade organic solvents were used throughout the investigation.

A $0.025 \%$ bromophenol blue (Loba Chemie Pvt. Ltd., Mumbai, India) and $0.1 \%$ bromothymol blue (Qualigens Fine Chemicals, Mumbai, India) solutions were prepared separately in dichloromethane (DCM, Merck, Mumbai, India; specific gravity 1.32) and used in method A and method B, respectively.

2.4. Standard ALB Solution. A stock standard solution containing $100 \mu \mathrm{g} \mathrm{mL}^{-1}$ ALB was prepared by dissolving $10 \mathrm{mg}$ of pure drug in dichloromethane and diluting to mark with the same solvent in a $100 \mathrm{~mL}$ calibrated flask. This was diluted appropriately with the same solvent to obtain working concentration of $30 \mu \mathrm{g} \mathrm{mL}^{-1}$ for method A and $40 \mu \mathrm{g} \mathrm{mL}^{-1}$ ALB for method B.

\subsection{Assay Procedures}

2.5.1. Method A (Using Bromophenol Blue, BPB). Different aliquots of $0.25,0.5,1.0,2.0,3.0$, and $3.5 \mathrm{~mL}$ of standard ALB solution $\left(30 \mu \mathrm{g} \mathrm{mL}^{-1}\right)$ were accurately transferred to $5 \mathrm{~mL}$ standard flasks using a microburette, and the total volume was adjusted to $3.5 \mathrm{~mL}$ by adding adequate quantity of DCM. One $\mathrm{mL}$ of $0.025 \% \mathrm{BPB}$ was added to each flask and the mixture was diluted to the volume with DCM and mixed well. The absorbance of each solution was measured at $445 \mathrm{~nm}$ against a reagent blank after $5 \mathrm{~min}$.

2.5.2. Method B (Using Bromothymol Blue, BTB). Aliquots of $0.25,0.5,1.0,2.0,3.0,3.5$, and $4.0 \mathrm{~mL}$ of standard ALB solution $\left(40 \mu \mathrm{g} \mathrm{mL}^{-1}\right)$ were measured accurately and added to $5 \mathrm{~mL}$ calibrated flasks using a microburette, and the total volume was adjusted to $4.0 \mathrm{~mL}$ with DCM. One $\mathrm{mL}$ of $0.1 \%$ BTB was added to each flask and the mixture was diluted to the volume with DCM and mixed well. After $5 \mathrm{~min}$, the absorbance of each solution was measured at $460 \mathrm{~nm}$ against a reagent blank prepared simultaneously.

A standard graph was prepared by plotting absorbance against concentration, and the unknown concentration was read from the graph or computed from the regression equation derived using Beer's law data.

2.6. Procedure for Tablets. The content of ten tablets each containing $400 \mathrm{mg}$ ALB was weighed accurately and grounded 
into a fine powder. An accurately weighed quantity equivalent to $10 \mathrm{mg}$ of ALB was transferred into a $100 \mathrm{~mL}$ calibrated flask and dissolved in $60 \mathrm{~mL}$ of DCM. The content was shaken thoroughly for $15-20 \mathrm{~min}$, diluted to the mark with DCM, mixed well, and filtered using a Whatman no. 42 filter paper. The first $10 \mathrm{~mL}$ portion of the filtrate was discarded, and a suitable aliquot of the filtrate $\left(100 \mu \mathrm{g} \mathrm{mL}^{-1}\right)$ was diluted to obtain working concentration of $30 \mu \mathrm{g} \mathrm{mL}^{-1}$ in method A and $40 \mu \mathrm{g} \mathrm{mL}^{-1}$ in method B with DCM and was analysed by taking an appropriate volume in both methods.

2.7. Procedure for the Selectivity Study. Selectivity was evaluated by using placebo blank and synthetic mixture analysis. A placebo blank, consisting of starch (20 mg), acacia (25 mg), hydroxyl cellulose $(20 \mathrm{mg})$, sodium citrate $(30 \mathrm{mg})$, talc $(20 \mathrm{mg})$, magnesium stearate $(25 \mathrm{mg})$, and sodium alginate (20 $\mathrm{mg}$ ), was prepared by thorough mixing and its solutions described under procedure for tablets and then were subjected to analysis.

A synthetic mixture was prepared by adding $10 \mathrm{mg}$ of pure ALB to $\sim 10 \mathrm{mg}$ of the above mentioned placebo blank, and the mixture was homogenized. Following the procedure used for tablets, the synthetic mixture solution was prepared, and a suitable quantity was subjected to analysis by both methods $(n=3)$ after appropriate dilution.

\section{Results and Discussion}

3.1. Absorption Spectra. The reaction of BPB or BTB with ALB results in the formation of intense yellow coloured product. The absorption of coloured products was recorded at 360$520 \mathrm{~nm}$ against the corresponding reagent blank solutions. The resulting coloured ion pair complexes showed maximum absorbance at $445 \mathrm{~nm}$ and $460 \mathrm{~nm}$ for ALB-BPB (a) and ALBBTB (b), respectively. Thus, all absorbance measurements were thus made at these wavelengths (Figure 1).

3.2. Reaction Pathway. ALB forms ion-pair complexes with dyes such as BPB and BTB, since it contains a tertiary amino group which is protonated in the solvent medium used. Chemically, the structure of ALB features its basic nature. This structure suggests the possibility of utilizing an anionic dye as chromogenic reagent. In dichloromethane, $A L B$ does not absorb in the visible region. In contrast, when a solution of BPB/BTB in dichloromethane is added to the drug solution, an intense yellow coloured product is produced immediately. This is due to an opening of lactoid ring of the dye and subsequent formation of quinoid group [46]. It is supposed that the two tautomers are present in equilibrium but due to strong acidic nature of the sulfonic acid group, the quinoid body must predominate. Finally, protonated ALB forms ion-pair with the anionic dye. The possible reaction pathway is shown in Schemes 1 and 2. Anionic dye as $\mathrm{BPB}$ or BTB forms ion-pair complex with positively charged drug. Each drug-dye ion-pair complex molecule, with two oppositely charged ions, behaves as a single unit held together by an electrostatic force of attraction (Schemes 1 and 2).
TABLE 1: Sensitivity and regression parameters.

\begin{tabular}{lcc}
\hline Parameter & Method A & Method B \\
\hline$\lambda_{\text {max }}, \mathrm{nm}$ & 445 & 460 \\
Colour stability, min & 90 & 60 \\
Linear range, $\mu \mathrm{g} \mathrm{mL}^{-1}$ & $1.5-21.0$ & $2.0-32.0$ \\
Molar absorptivity $(\varepsilon), \mathrm{L} \mathrm{mol}^{-1} \mathrm{~cm}^{-1}$ & $1.27 \times 10^{4}$ & $7.57 \times 10^{3}$ \\
Sandell sensitivity ${ }^{*}, \mu \mathrm{g} \mathrm{cm}^{-2}$ & 0.0209 & 0.0350 \\
Limit of detection (LOD), $\mu \mathrm{g} \mathrm{mL}^{-1}$ & 0.01 & 0.16 \\
Limit of quantification (LOQ), $\mu \mathrm{g} \mathrm{mL}^{-1}$ & 0.02 & 0.49 \\
Regression equation, $Y^{* *}$ & & \\
Intercept ( $a$ ) & 0.0358 & 0.0049 \\
Slope ( $b$ ) & 0.042 & 0.028 \\
Standard deviation of $a\left(S_{a}\right)$ & $9.98 \times 10^{-2}$ & $9.98 \times 10^{-2}$ \\
Standard deviation of $b\left(S_{b}\right)$ & $5.53 \times 10^{-3}$ & $3.39 \times 10^{-3}$ \\
Regression coefficient $(r)$ & 0.9975 & 0.9997 \\
\hline
\end{tabular}

${ }^{*}$ Limit of determination as the weight in $\mu \mathrm{g} \mathrm{mL}{ }^{-1}$ of solution, which corresponds to an absorbance of $A=0.001$ measured in a cuvette of crosssectional area $1 \mathrm{~cm}^{2}$ and $l=1 \mathrm{~cm}$.

${ }^{* *} Y=a+b X$, where $Y$ is the absorbance, $X$ is concentration in $\mu \mathrm{g} \mathrm{mL}^{-1}, a$ is intercept, and $b$ is slope.

\subsection{Optimisation of Reaction Conditions}

3.3.1. Effect of Reagent Concentration. The effect of the dye concentration on the intensity of the colour developed at selected wavelengths was studied by measuring the absorbances of solutions containing a fixed concentration of ALB and different amounts $(0.5-2.5 \mathrm{~mL})$ of the respective dye of $0.025 \%$ BPB and $0.1 \%$ BTB solution. Maximum colour intensity was achieved with $1 \mathrm{~mL}$ of dye in each case and excess dye did not affect the absorbance of the complex (Figure 2).

3.3.2. Effect of Solvent. In order to select the suitable solvent for ion-pair complex formation, the reaction of ALB with BPB and BTB was carried out in different solvents such as DCM, chloroform, acetonitrile, methanol, 1,2-dichloroethane, 1,4dioxane, and benzene. The DCM was found to be ideal solvent for both methods A and B (Figure 3). Similarly, the effect of the diluting solvent was studied for both methods and the results showed that DCM was best suited for both methods with low blank absorbance and high complex absorbance.

3.3.3. Effect of Reaction Time and Stability of Colour. The addition of the dye solution resulted in an immediate full colour development at ambient temperature and the formed ion-pair complexes were stable for at least $1.5 \mathrm{~h}$ in method $\mathrm{A}$ and half an hour in method $\mathrm{B}$. The reaction was found to be complete quantitative when the reaction mixture was allowed to stand for $5 \mathrm{~min}$.

3.3.4. Stoichiometric Relationship. Job's method of continuous variations of equimolar solutions was employed to establish the stoichiometry of formed ion-pair complexes. Solutions equivalent to $1.13 \times 10^{-4} \mathrm{M}$ ALB and BPB were 
<smiles>O=S1(=O)OC(c2cc(Br)c(O)c(Br)c2)(c2cc(Br)c(O)c(Br)c2)c2ccccc21</smiles>

$\mathrm{BPB}$<smiles>C=CC=CC</smiles>

$\mathrm{BPB}$ (quinoid ring)<smiles>O=C1C(Br)=CC(=C(c2cc(Br)c(O)c(Br)c2)c2ccccc2S(=O)(=O)[O-])C=C1Br</smiles>

$\mathrm{BPB}^{-}$

anionic form<smiles>CCCSc1ccc2[nH]c(NC(=O)OC)[nH+]c2c1</smiles>

ALB

$$
\mathrm{ALBH}^{+}+\mathrm{BPB}^{-} \longrightarrow \begin{gathered}
{\left[\mathrm{ALBH}^{+}-\mathrm{BPB}^{-}\right]} \\
\begin{array}{c}
\mathrm{ALB}-\mathrm{BPB} \text { ion-pair complex } \\
\text { measured at } 445 \mathrm{~nm}
\end{array}
\end{gathered}
$$

\begin{tabular}{|c|c|c|c|c|c|c|c|}
\hline \multirow[b]{2}{*}{ Method } & \multirow[b]{2}{*}{$\begin{array}{c}\text { ALB } \\
\text { taken } \\
\left(\mu \mathrm{g} \mathrm{mL}^{-1}\right)\end{array}$} & \multicolumn{3}{|c|}{ Intra-day accuracy and precision $(n=7)$} & \multicolumn{3}{|c|}{ Inter-day accuracy and precision $(n=7)$} \\
\hline & & $\begin{array}{c}\text { ALB } \\
\text { found }^{\mathrm{a}} \\
\left(\mu \mathrm{g} \mathrm{mL}^{-1}\right)\end{array}$ & $\operatorname{RSD}^{\mathrm{b}} \%$ & $\mathrm{RE}^{\mathrm{c}} \%$ & $\begin{array}{c}\text { ALB } \\
\text { found } \\
\left(\mu \mathrm{g} \mathrm{mL}^{-1}\right)\end{array}$ & $\mathrm{RSD}^{\mathrm{b}} \%$ & $\mathrm{RE}^{\mathrm{c}} \%$ \\
\hline \multirow{3}{*}{ A } & 6.0 & 6.05 & 1.27 & 0.84 & 6.10 & 0.79 & 1.67 \\
\hline & 12.0 & 12.15 & 0.99 & 1.25 & 12.23 & 0.55 & 1.92 \\
\hline & 18.0 & 18.25 & 2.25 & 1.39 & 18.37 & 1.33 & 2.06 \\
\hline \multirow{3}{*}{ B } & 8.0 & 8.09 & 1.40 & 1.10 & 8.07 & 2.35 & 1.90 \\
\hline & 16.0 & 16.27 & 1.32 & 1.68 & 16.35 & 1.13 & 2.18 \\
\hline & 24.0 & 24.30 & 2.18 & 1.25 & 24.48 & 1.31 & 2.01 \\
\hline
\end{tabular}

Scheme 1: Reaction mechanism for the formation of ALB-BPB ion-pair complex.

TABLE 2: Evaluation of Intra-day and inter-day accuracy and precision.

${ }^{a}$ Mean value of 7 determinations; ${ }^{b}$ relative standard deviation (\%); ${ }^{c}$ relative error (\%).

prepared in DCM in method A, and $3.02 \times 10^{-4} \mathrm{M}$ ALB and BTB were prepared in method B by dissolving the calculated quantities in DCM. A series of solutions was prepared in which the total volume of ALB and reagent was kept at $3.0 \mathrm{~mL}$ in $5 \mathrm{~mL}$ calibrated flask. The solutions were well mixed; the volume was completed to the mark with DCM. The absorbance of the resulting solution was measured after $10 \mathrm{~min}$ at the respective wavelengths of maximum absorbance against the organic solvent as blank in the respective methods. The resulting graph (Figure 4) shows that the interaction occurs on an equimolar basis (1:1 reaction stoichiometry), owing to the presence of one basic nitrogen containing group in the ALB molecule.

The conditional stability constant $\left(K_{f}\right)$ of the ionassociation complex was calculated from the continuous variations data using the following equation [47]:

$$
K_{f}=\frac{A / A_{m}}{\left[1-A / A_{m}\right]^{n+2} C_{M}(n)^{n}},
$$

where $A$ and $A_{m}$ are the observed maximum absorbance and the absorbance value when all the drug present is associated, respectively. $C_{M}$ is the molar concentration of drug at the maximum absorbance and $n$ is the stoichiometry with which $\mathrm{BPB} / \mathrm{BTB}$ ion associates with ALB ion. The $\log K_{f}$ values were found to be 7.58 and 6.62 for method A and method B, respectively.

\subsection{Method Validation}

3.4.1. Linearity, Sensitivity, Limits of Detection, and Quantification. A linear correlation was found between absorbance at $\lambda_{\text {max }}$ and concentration of ALB in the ranges given in Table 1. The graphs are described by the regression equation:

$$
Y=a+b X
$$

where $Y=$ absorbance of $1 \mathrm{~cm}$ layer of solution, $a=$ intercept, $b=$ slope, and $X=$ concentration in $\mu \mathrm{g} \mathrm{mL}^{-1}$. Regression analysis of the Beer's law data using the method of least squares was made to evaluate the slope $(b)$, intercept $(a)$, and 


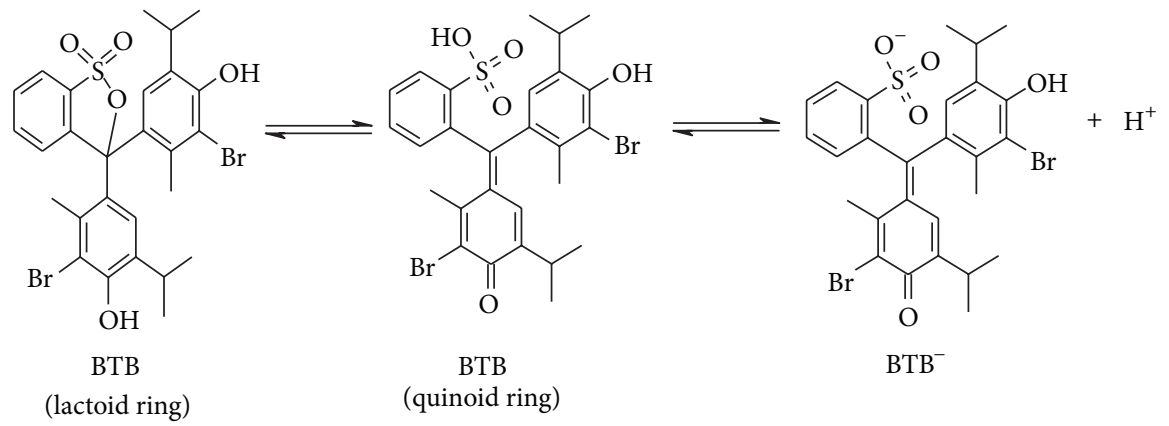<smiles></smiles>

Protonated ALB

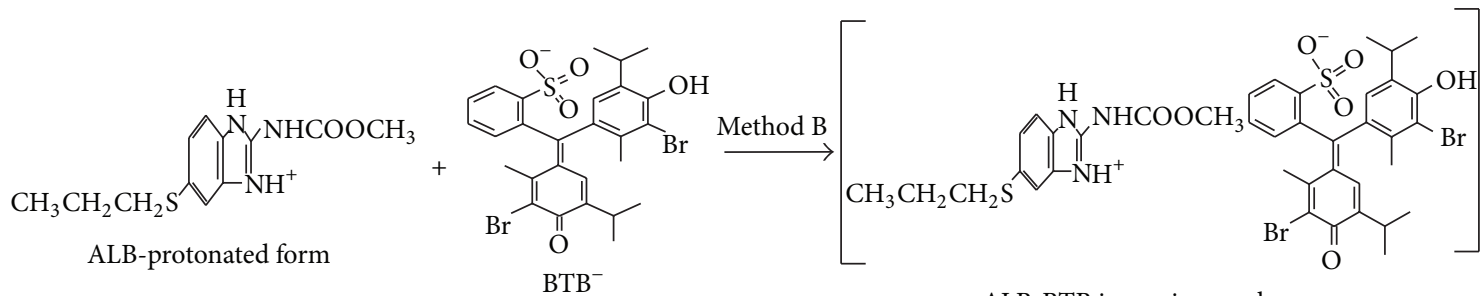

ALB-BTB ion-pair complex measured at $460 \mathrm{~nm}$ Scheme 2: Reaction mechanism for the formation of ALB-BTB ion-pair complex.

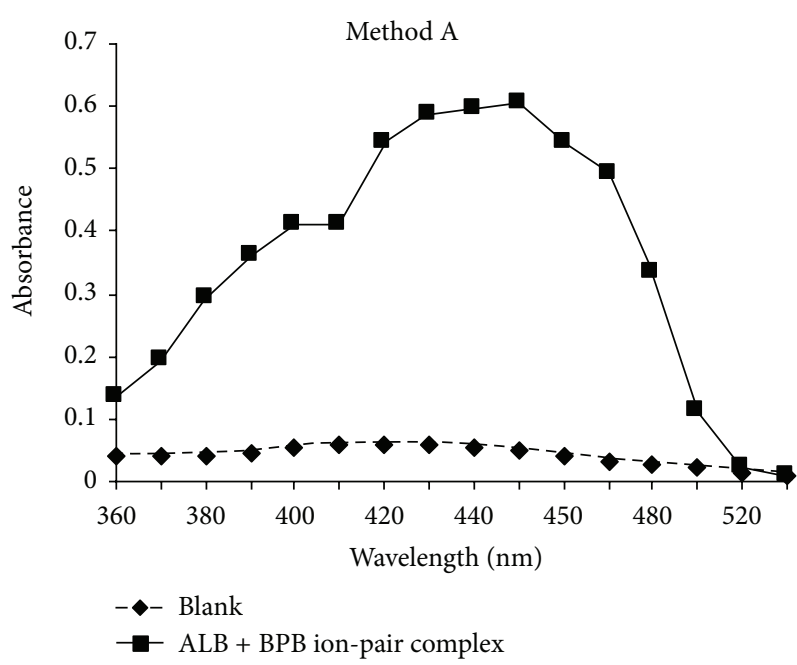

(a)

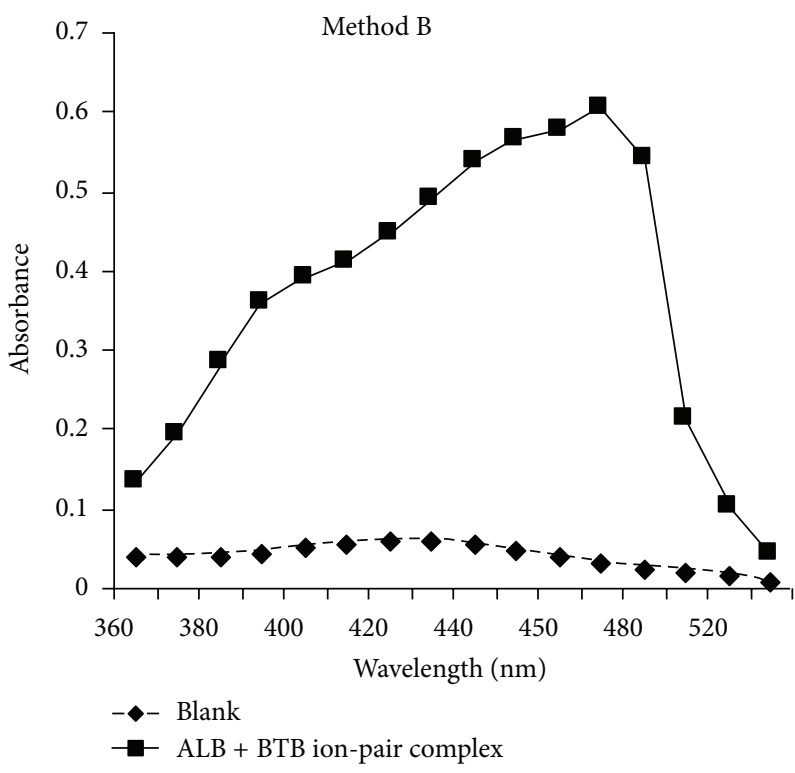

(b)

FIgURE 1: Absorption spectra. 


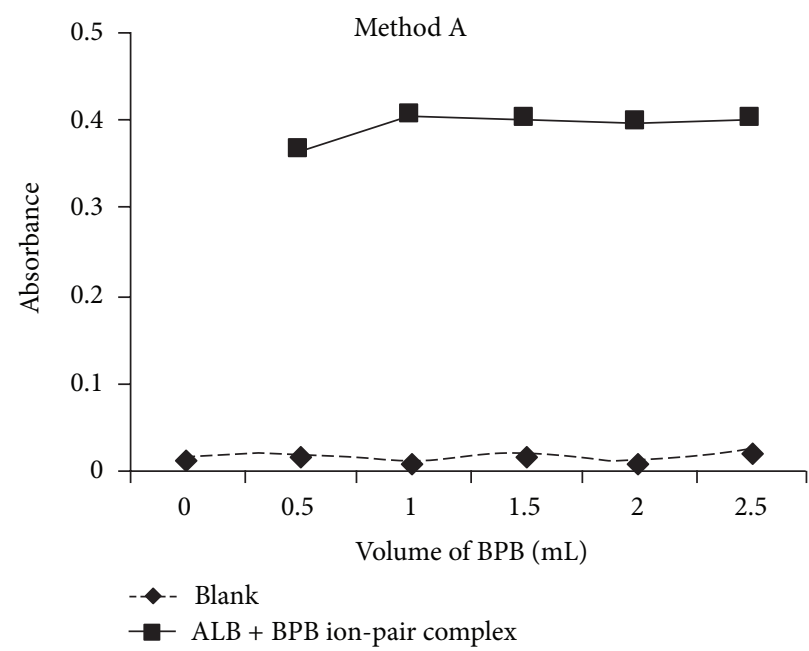

(a)

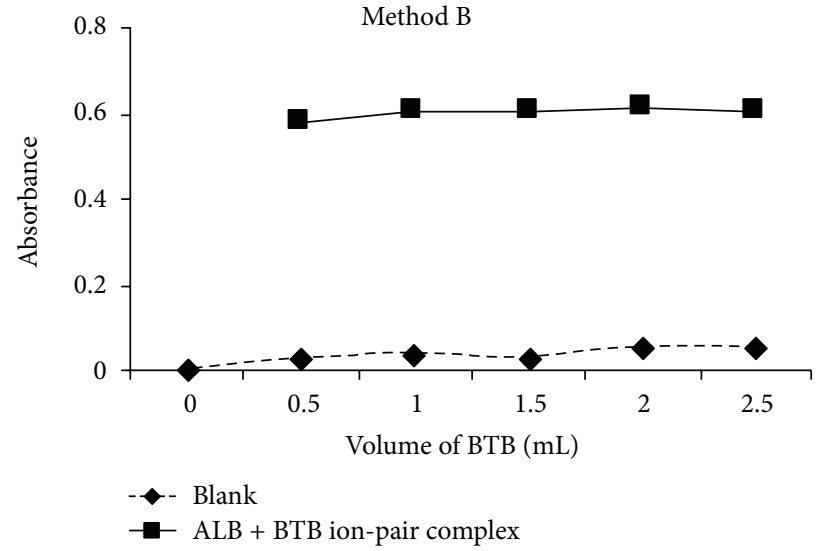

(b)

Figure 2: Effect of reagent volume of (a) $0.05 \%$ BPB and (b) $0.1 \%$ BTB dye solution on the absorbance of ion-pair complex and blank $\left(8 \mu \mathrm{g} \mathrm{mL}^{-1}\right.$ ALB in method A and $20 \mu \mathrm{g} \mathrm{mL}^{-1}$ in method B).

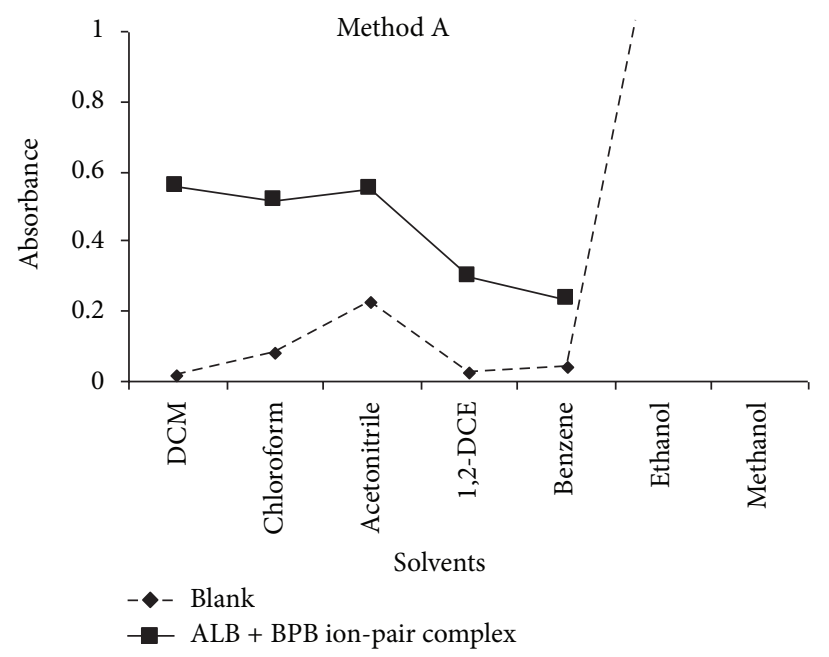

(a)

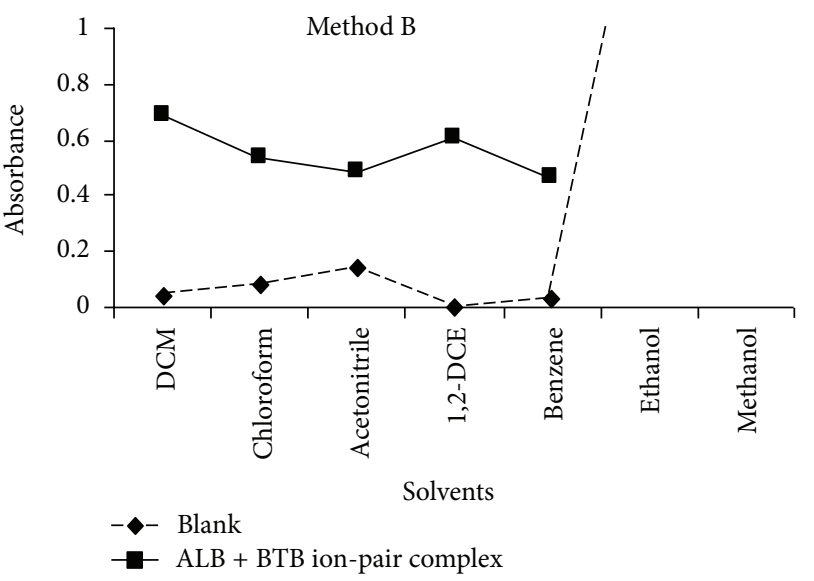

(b)

FIgURE 3: Effect of solvent ( $8 \mu \mathrm{g} \mathrm{mL}^{-1}$ ALB in method A and $20 \mu \mathrm{g} \mathrm{mL}^{-1}$ in method B).

TABLE 3: Method robustness and ruggedness expressed as intermediate precision.

\begin{tabular}{|c|c|c|c|c|}
\hline \multirow[b]{2}{*}{ Method } & \multicolumn{2}{|c|}{ Method robustness } & \multicolumn{2}{|c|}{ Method ruggedness } \\
\hline & $\begin{array}{l}\text { ALB taken } \\
\left(\mu \mathrm{g} \mathrm{mL}^{-1}\right)\end{array}$ & $\begin{array}{c}\text { Parameters altered, } \\
\text { volume of BPB/BTB } \\
\mathrm{mL}^{\mathrm{a}} \% \mathrm{RSD} \\
(n=3)\end{array}$ & $\begin{array}{l}\text { Interanalysts } \\
(\% \mathrm{RSD}) \\
(n=4)\end{array}$ & $\begin{array}{c}\text { Interinstruments } \\
(\% \mathrm{RSD}), \\
(n=4)\end{array}$ \\
\hline \multirow{3}{*}{ A } & 6.0 & 2.16 & 2.49 & 2.52 \\
\hline & 12.0 & 1.80 & 1.84 & 1.92 \\
\hline & 18.0 & 1.94 & 2.02 & 2.14 \\
\hline \multirow{3}{*}{ B } & 8.0 & 2.11 & 2.46 & 2.75 \\
\hline & 16.0 & 1.65 & 1.94 & 2.07 \\
\hline & 24.0 & 1.74 & 2.06 & 2.35 \\
\hline
\end{tabular}

\footnotetext{
${ }^{a}$ In both methods, the volumes of reagent were $1 \pm 0.1 \mathrm{~mL}$.
} 


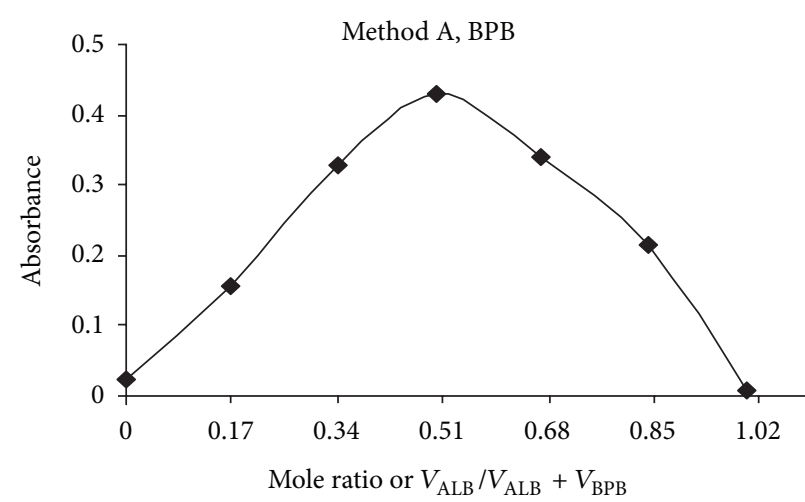

(a)

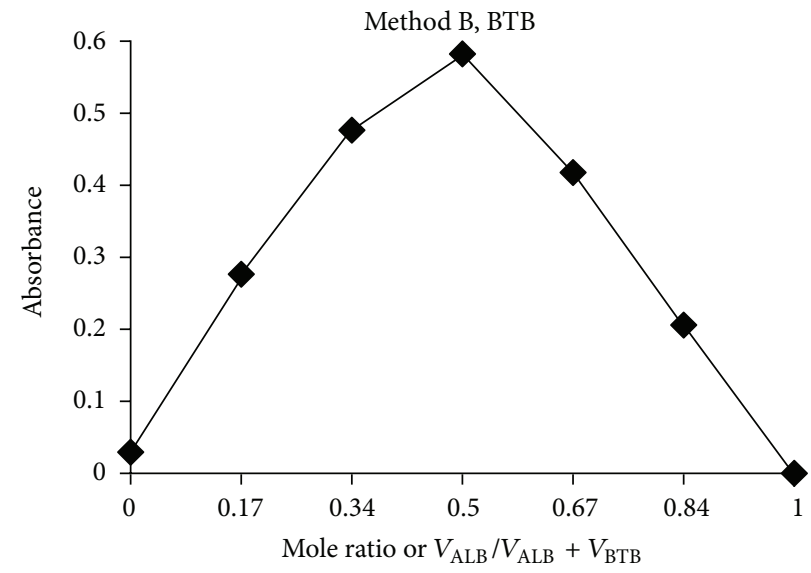

(b)

FIGURE 4: Job's continuous variations plot for (a) ALB-BPB ion-pair complex $V_{\mathrm{ALB}}$ and $V_{\mathrm{BPB}}$ are volumes of ALB and BPB (both $\left.1.13 \times 10^{-4} \mathrm{M}\right)$, respectively, and (b) ALB-BTB ion-pair complex $V_{\mathrm{ALB}}$ and $V_{\mathrm{BPB}}$ are volumes of ALB and BTB (both $3.02 \times 10^{-4} \mathrm{M}$ ), respectively.

TABLE 4: Results of analysis of tablets by the proposed methods.

\begin{tabular}{|c|c|c|c|c|}
\hline \multirow{3}{*}{ Tablets analysed } & \multirow{3}{*}{ Label claim, mg/tablet } & \multicolumn{3}{|c|}{ Found* (Percent of label claim \pm SD) } \\
\hline & & \multirow{2}{*}{ Reference method } & \multicolumn{2}{|c|}{ Proposed methods } \\
\hline & & & Method A & Method B \\
\hline \multirow{3}{*}{ Alworm 400} & \multirow{3}{*}{400} & \multirow{3}{*}{$101.2 \pm 0.75$} & $100.5 \pm 1.20$ & $101.8 \pm 1.01$ \\
\hline & & & $t=1.11$ & $t=1.07$ \\
\hline & & & $F=2.56$ & $F=1.81$ \\
\hline \multirow{3}{*}{ ABD 400} & \multirow{3}{*}{400} & \multirow{3}{*}{$99.8 \pm 0.56$} & $99.9 \pm 1.19$ & $100.8 \pm 1.25$ \\
\hline & & & $t=0.17$ & $t=1.63$ \\
\hline & & & $F=4.52$ & $F=4.98$ \\
\hline \multirow{3}{*}{ Bandy 400} & \multirow{3}{*}{400} & \multirow{3}{*}{$100.8 \pm 0.78$} & $100.3 \pm 1.69$ & $100.7 \pm 1.55$ \\
\hline & & & $t=0.6$ & $t=0.13$ \\
\hline & & & $F=4.69$ & $F=3.95$ \\
\hline
\end{tabular}

${ }^{*}$ Mean value of five determinations.

Tabulated $t$ value at the $95 \%$ confidence level is 2.78 .

Tabulated $F$ value at the $95 \%$ confidence level is 6.39 .

correlation coefficient $(r)$ for each system and the values are presented in Table 1. The optical characteristics such as Beer's law limits, molar absorptivity, and Sandell's sensitivity values [48] of all the three methods are also given in Table 1.

The limits of detection (LOD) and quantitation (LOQ) calculated according to ICH guidelines [49] using the following formulae:

$$
\mathrm{LOD}=\frac{3.3 S}{b}, \quad \mathrm{LOQ}=\frac{10 S}{b},
$$

where $S$ is the standard deviation of blank absorbance values, and $b$ is the slope of the calibration plot are also presented in Table 1. The values of $\varepsilon$ and Sandell's sensitivity and LOD indicate the sensitivity of the proposed methods.

3.5. Accuracy and Precision. To evaluate the accuracy and precision of the proposed methods, pure ALB solution at three different concentration levels (within working range) was prepared and analyzed in seven replicates during the same day (intraday precision) and on five consecutive days (interday precision) and the results are presented in Table 2. The percentage relative error ( $\mathrm{RE} \%$ ) was $\leq 2.18$ which indicate that the accuracy of the methods is satisfactory. Percentage relative standard deviation (RSD \%) for intraday was $\leq 2.25$ and for interday was $\leq 2.35$ indicating repeatability and usefulness of the proposed methods in the analysis.

3.6. Selectivity. In order to evaluate the selectivity of the proposed methods for the analysis of pharmaceutical formulations, the effect of the presence of common excipients was tested for possible interference in the assay by placebo blank and synthetic mixture analyses. The absorbance of the reaction product with the placebo blank was almost equal to the absorbance of the reagent blank suggesting no interference from the tablet excipients. The percent recoveries of ALB were $98.3 \pm 2.2$ and $101.2 \pm 2.6$ for methods A and B, respectively. This confirms the selectivity of the methods in the presence of the common tablet excipients. 
TABLE 5: Results of recovery study via standard addition method with tablet.

\begin{tabular}{|c|c|c|c|c|c|}
\hline Method & Tablet studied & $\begin{array}{c}\text { ALB in tablet } \\
\mu \mathrm{g} \mathrm{mL}^{-1}\end{array}$ & $\begin{array}{c}\text { Pure ALB added } \\
\mu \mathrm{g} \mathrm{mL}^{-1}\end{array}$ & $\begin{array}{c}\text { Total found } \\
\mu \mathrm{g} \mathrm{mL}\end{array}$ & Pure ALB recovered ${ }^{*}$ percent $\pm S D$ \\
\hline \multirow{9}{*}{ A } & \multirow{3}{*}{ Alworm 400} & 6.03 & 3.0 & 9.07 & $101.30 \pm 1.52$ \\
\hline & & 6.03 & 6.0 & 12.13 & $101.70 \pm 1.61$ \\
\hline & & 6.03 & 9.0 & 15.07 & $100.50 \pm 2.11$ \\
\hline & \multirow{3}{*}{ ABD 400} & 5.99 & 3.0 & 8.97 & $99.34 \pm 1.89$ \\
\hline & & 5.99 & 6.0 & 12.00 & $100.20 \pm 2.34$ \\
\hline & & 5.99 & 9.0 & 14.96 & $99.74 \pm 2.30$ \\
\hline & \multirow{3}{*}{ Bandy 400} & 6.02 & 3.0 & 9.03 & $100.40 \pm 2.07$ \\
\hline & & 6.02 & 6.0 & 11.99 & $99.50 \pm 2.59$ \\
\hline & & 6.02 & 9.0 & 15.01 & $99.96 \pm 2.81$ \\
\hline \multirow{9}{*}{ B } & \multirow{3}{*}{ Alworm 400} & 8.14 & 4.0 & 12.16 & $100.60 \pm 1.31$ \\
\hline & & 8.14 & 8.0 & 16.15 & $100.20 \pm 2.56$ \\
\hline & & 8.14 & 12.0 & 20.13 & $99.91 \pm 2.48$ \\
\hline & \multirow{3}{*}{$\mathrm{ABD} 400$} & 8.06 & 4.0 & 12.09 & $100.90 \pm 1.49$ \\
\hline & & 8.06 & 8.0 & 16.15 & $101.20 \pm 1.56$ \\
\hline & & 8.06 & 12.0 & 20.13 & $100.60 \pm 2.48$ \\
\hline & \multirow{3}{*}{ Bandy 400} & 8.05 & 4.0 & 12.03 & $99.45 \pm 1.35$ \\
\hline & & 8.05 & 8.0 & 16.15 & $101.30 \pm 2.56$ \\
\hline & & 8.05 & 12.0 & 20.13 & $100.70 \pm 2.48$ \\
\hline
\end{tabular}

${ }^{*}$ Mean value of three determinations.

3.7. Robustness and Ruggedness. To determine the robustness of the proposed methods, an important experimental variable, volume of reagent was slightly varied and the effect of this change on the absorbance of the ion-pair complex was studied. The results of this effect are presented in Table 3 and indicated that the proposed methods are robust. Method ruggedness was evaluated by performing the analysis following the general procedures by three different analysts and on three different spectrophotometers by the same analyst. From the $\%$ RSD values presented in Table 3 , it is concluded that the proposed methods are rugged.

3.8. Application for Tablets. The proposed methods were applied to the determination of ALB in tablets. The results obtained were statistically compared with those of the official method [3] by applying Student's $t$-test for accuracy and Ftest for precision. The official method describes a potentiometric titration with perchloric acid in formic acid-acetic acid medium. As can be seen from Table 4, the calculated $t$ and $F$ values at 95\% confidence level did not exceed the tabulated values of 2.78 and 6.39 , respectively, for four degrees of freedom. The results showed that there is no difference between the proposed methods and the official method with respect to accuracy and precision.

3.9. Recovery Study. To further assess the accuracy of the methods, recovery experiments were performed by applying the standard-addition technique. The recovery was assessed by determining the agreement between the measured standard concentration and added known concentration to the sample. The test was done by spiking the preanalysed tablet powder with pure ALB at three different levels 50, 100, and $150 \%$ of the content present in the tablet powder (taken) and the total was found by the proposed methods. Each test was repeated three times. In all the cases, the recovery percentage values ranged between $99.34 \%$ and $101.7 \%$ with standard deviation in the range $1.31 \%-2.81 \%$. Closeness of the results to $100 \%$ showed the fairly good accuracy of the methods. The results are shown in Table 5 .

\section{Conclusions}

Two spectrophotometric methods for the determination of albendazole in bulk drug and in tablets were developed and validated for accuracy, precision, linearity, robustness, and ruggedness. The methods employ more normal conditions than those previously reported and rely on well-characterised ion-pair formation reactions. Besides, the methods have the advantages of simplicity without involving heating or extraction step and high sensitivity. The proposed methods are rapid, simple and in addition offer advantages in determining ALB (in tablets), when extraction difficulties arise with other spectrophotometric methods based on ion-pair extraction (Table 6). Hence, the proposed methods could be adopted for quality control in pharmaceutical industries.

\section{Acknowledgments}

The authors express their gratitude to the quality control manager, Cipla India, Ltd., Mumbai, India, for gift sample of pure albendazole. The first author (Nagaraju Swamy) is grateful to the authorities of the University of Mysore, 
TABLE 6: Comparison of the performance characteristics of the present methods with the published method Spectrophotometry.

\begin{tabular}{|c|c|c|c|c|c|c|}
\hline $\begin{array}{l}\text { Serial } \\
\text { number }\end{array}$ & Reagentes used & Methodology & $\begin{array}{l}\lambda_{\max } \\
(\mathrm{nm})\end{array}$ & $\begin{array}{c}\text { Linear range } \\
\left(\mu \mathrm{g} / \mathrm{mL}^{-1}\right) \\
\varepsilon\left(\mathrm{L} \mathrm{mol}^{-1} \mathrm{~cm}^{-1}\right)\end{array}$ & Remarks & Reference \\
\hline 1 & $\begin{array}{l}\text { CAT-methyl } \\
\text { orange/indigocarmine }\end{array}$ & $\begin{array}{l}\text { Unreacted CAT measured } \\
\text { using methyl } \\
\text { orange/indigocarmine in acid } \\
\text { medium }\end{array}$ & $\begin{array}{l}510 \\
610\end{array}$ & - & $\begin{array}{l}\text { Employs unstable } \\
\text { oxidant }\end{array}$ & {$[6]$} \\
\hline 2 & $\begin{array}{l}\text { CAT-metol-Ar. } \\
\text { aldehyde }\end{array}$ & $\begin{array}{l}\text { Measurement of unreacted } \\
\text { CAT with metol and Ar. } \\
\text { aldehyde at pH } 2.70 \pm 0.1\end{array}$ & 520 & $\begin{array}{c}2.5-25 \\
6.24 \times 10^{3}\end{array}$ & $\begin{array}{l}\text { Employs unstable } \\
\text { oxidant, multiple } \\
\text { step reaction, strict } \\
\text { pH control }\end{array}$ & [7] \\
\hline 3 & $\begin{array}{l}\mathrm{KBrO}_{3}-\mathrm{KBr} \\
\text { mixture-MO }\end{array}$ & $\begin{array}{l}\text { Kinetic measurement of } \\
\text { unreacted bromine using } \\
\text { methyl orange }\end{array}$ & 510 & $\begin{array}{c}0.5-4.0 \\
2.89 \times 10^{4}\end{array}$ & $\begin{array}{l}\text { Strict control of } \\
\text { experimental } \\
\text { variables } \\
\text { required } \\
\end{array}$ & {$[8]$} \\
\hline 4 & $\begin{array}{l}\mathrm{KBrO}_{3}-\mathrm{KBr} \text { mixture in } \\
\text { acid medium }\end{array}$ & $\begin{array}{l}\text { Measurement of residual } \\
\text { bromine using methyl orange } \\
\text { in acid medium }\end{array}$ & - & $5-25$ & - & [9] \\
\hline \multirow[t]{2}{*}{5} & \multirow[t]{2}{*}{$\begin{array}{l}\text { NBS-methyl } \\
\text { orange/indigo carmine }\end{array}$} & \multirow{2}{*}{$\begin{array}{l}\text { Measurement of absorbance } \\
\text { of acid form of methyl orange } \\
\text { or indigocarmine }\end{array}$} & 520 & $\begin{array}{c}1.5-4.0 \\
3.45 \times 10^{4}\end{array}$ & \multirow[t]{2}{*}{$\begin{array}{l}\text { Employs unstable } \\
\text { oxidant }\end{array}$} & \multirow[t]{2}{*}[10]{} \\
\hline & & & 610 & $\begin{array}{c}8-16 \\
1.13 \times 10^{4} \\
\end{array}$ & & \\
\hline 6 & NCS-Fe (II)-SCN ${ }^{-}$ & $\begin{array}{l}\text { Measurement of absorbance } \\
\text { of iron (III)-SCN }{ }^{-} \text {complex }\end{array}$ & 480 & $\begin{array}{l}0.62-10.0 \\
4.14 \times 10^{4}\end{array}$ & $\begin{array}{l}\text { Employs unstable } \\
\text { oxidant, multiple } \\
\text { step } \\
\text { reaction and multi } \\
\text { reagents }\end{array}$ & {$[11]$} \\
\hline \multirow[t]{2}{*}{7} & \multirow[t]{2}{*}{$\mathrm{NaIO}_{4}$} & \multirow{2}{*}{$\begin{array}{l}\text { Measurement of acid form of } \\
\text { methyl orange or indigo } \\
\text { carmine }\end{array}$} & 520 & $\begin{array}{c}0.5-5.0 \\
2.92 \times 10^{4}\end{array}$ & \multirow[t]{2}{*}{-} & \multirow[t]{2}{*}[12]{} \\
\hline & & & 610 & $\begin{array}{c}2.5-25 \\
5.11 \times 10^{3} \\
\end{array}$ & & \\
\hline 8 & $\begin{array}{l}\text { NBS-iron-(II-) } \\
\text { thiocyanate or tiron }\end{array}$ & $\begin{array}{l}\text { Measurement of absorbance } \\
\text { of iron-(III-) thiocyanate or } \\
\text { tiron complex }\end{array}$ & - & $\begin{array}{c}0.5-5.0 \\
4.8 \times 10^{4} \\
1-21 \\
1.1 \times 10^{4} \\
\end{array}$ & $\begin{array}{l}\text { Employs unstable } \\
\text { oxidant }\end{array}$ & {$[30]$} \\
\hline 9 & $\begin{array}{l}\text { Folin-Ciocalteu's } \\
\text { reagent }\end{array}$ & $\begin{array}{l}\text { Measurement of the } \\
\text { absorbance of blue colored } \\
\text { chromogen }\end{array}$ & 700 & - & - & {$[32]$} \\
\hline 10 & ${ }^{*} p-\mathrm{CA}$ & $\begin{array}{l}\text { Measurement of absorbance of } \\
\text { charge transfer complex } \\
\text { radical anion }\end{array}$ & 525 & $\begin{array}{c}0 \sim 280 \\
8.03 \times 103\end{array}$ & Less sensitive & {$[33]$} \\
\hline \multirow[t]{2}{*}{11} & (a) DDQ & \multirow{2}{*}{$\begin{array}{l}\text { Measurement of absorbance of } \\
\text { charge transfer complex } \\
\text { radical anion }\end{array}$} & 500 & $\begin{array}{c}7.50-80 \\
1.83 \times 10^{3}\end{array}$ & \multirow[t]{2}{*}{ Less sensitive } & \multirow[t]{2}{*}[34]{} \\
\hline & (b) $p$-CAA & & 455 & $\begin{array}{c}10-85 \\
1.12 \times 10^{3} \\
\end{array}$ & & \\
\hline 12 & $\begin{array}{l}{ }^{*} \mathrm{BCG}, \mathrm{BTB}, \mathrm{BPB} \text {, and } \\
\text { BPR in acidic medium }\end{array}$ & $\begin{array}{l}\text { Measurement of absorbance } \\
\text { of the ion-pair complex }\end{array}$ & 420 & $2-12$ & $\begin{array}{l}\text { Involves tedious } \\
\text { extraction step, } \\
\text { rigid pH control, } \\
\text { and use of large } \\
\text { quantity of organic } \\
\text { solvent }\end{array}$ & {$[35]$} \\
\hline 13 & $\begin{array}{l}\text { Thymol blue, alizarin } \\
\text { (I), alizarin red S (II), } \\
\text { alizarin yellow (III), } \\
\text { quinalizarin (IV), } \\
\text { alizarin fluorine blue } \\
\text { (V), and thymol blue } \\
\text { (VI) }\end{array}$ & $\begin{array}{l}\text { Measurement of } \\
\text { ion-pair complex }\end{array}$ & - & $6.6-92.8$ & $\begin{array}{l}\text { Involves tedious } \\
\text { extraction step, } \\
\text { rigid pH control, } \\
\text { and use of large } \\
\text { quantity of organic } \\
\text { solvent, less } \\
\text { sensitive }\end{array}$ & {$[36]$} \\
\hline
\end{tabular}


TABLE 6: Continued.

\begin{tabular}{|c|c|c|c|c|c|c|}
\hline $\begin{array}{l}\text { Serial } \\
\text { number }\end{array}$ & Reagentes used & Methodology & $\begin{array}{l}\lambda_{\max } \\
(\mathrm{nm})\end{array}$ & $\begin{array}{c}\begin{array}{c}\text { Linear range } \\
\left(\mu \mathrm{g} / \mathrm{mL}^{-1}\right)\end{array} \\
\varepsilon\left(\mathrm{L} \mathrm{mol}^{-1} \mathrm{~cm}^{-1}\right) \\
\end{array}$ & Remarks & Reference \\
\hline \multirow[t]{2}{*}{14} & $\begin{array}{l}\text { NBS-metol- } \\
\text { sulfanilamide }\end{array}$ & $\begin{array}{l}\text { CT complex involving } \\
\text { metol-sulfanilamide measured }\end{array}$ & 520 & \multirow[t]{2}{*}{ - } & \multirow[t]{2}{*}{$\begin{array}{l}\text { Employs unstable } \\
\text { oxidant }\end{array}$} & \multirow[t]{2}{*}[37]{} \\
\hline & NBS-celesteine blue & $\begin{array}{l}\text { Measurement of absorbance } \\
\text { of CT complex }\end{array}$ & 540 & & & \\
\hline \multirow[t]{2}{*}{15} & (a) Bromophenol blue & $\begin{array}{l}\text { Measurement of absorbance } \\
\text { of yellow coloured ion-pair } \\
\text { complex in DCM }\end{array}$ & 445 & $\begin{array}{c}1.5-18.0 \\
1.27 \times 10^{4}\end{array}$ & $\begin{array}{l}\text { Simple, highly } \\
\text { sensitive, } \\
\text { extraction free, and } \\
\text { wide linear range }\end{array}$ & \multirow{2}{*}{$\begin{array}{l}\text { Present } \\
\text { work }\end{array}$} \\
\hline & (b) Bromothymol blue & $\begin{array}{l}\text { Absorbance of yellow } \\
\text { coloured ion-pair complex } \\
\text { should be measured in DCM }\end{array}$ & 460 & $\begin{array}{c}2.0-32.0 \\
7.57 \times 10^{3}\end{array}$ & $\begin{array}{l}\text { Simple, sensitive, } \\
\text { extraction free, and } \\
\text { wide linear range }\end{array}$ & \\
\hline
\end{tabular}

* BCG: bromo cresol green, BTB: bromo thymol blue, BPB: bromo phenol blue, BPR: bromo phenol red, $p$-CAA: chloranilic acid.

Mysore, India, for permission and facilities. The authors do not have any conflict of interests with the company name used in the paper.

\section{References}

[1] The Extra Pharmacopoeia, Royal Pharmaceutical Society of Great Britan, London, UK, 24th edition, 1989.

[2] L. Goodman and A. Gilman, The Pharmaceutical Basis of Therapeutics, Chapter 44, McMilan Publishing Company, New York, NY, USA, 7th edition, 1985.

[3] British Pharmacopoeia, The Stationary Office, London, UK, 2009.

[4] K. Basavaiah, P. Nagegowda, and V. Ramakrishna, "Titrimetric and spectrophotometric methods for the assay of albendazole in non-aqueous medium," Proceedings of the National Academy of Sciences, India, vol. 74, no. 3, pp. 271-276, 2004.

[5] N. De Laurentis, M. A. Milillo, and S. Bruno, "Determination of albendazole as raw material and in tablets by nonaqueous titration with sodium methylate solution," Revista de Farmacia e Bioquimica da Universidade de Sao Paulo, vol. 33, no. 1, pp. 23-27, 1997.

[6] K. Basavaiah and H. C. Prameela, "Use of an oxidation reaction for the quantitative determination of albendazole with chloramine-T and acid dyes," Analytical Sciences, vol. 19, no. 5, pp. 779-784, 2003.

[7] K. Basavaiah and H. C. Prameela, "Two simple methods for the estimation of albendazole and its dosage forms using chloramine-T," Farmaco, vol. 58, no. 7, pp. 527-534, 2003.

[8] K. Basavaiah and H. C. Prameela, "Kinetic and titrimetric determination of albendazole using bromate and methyl orange," Indian Journal of Pharmaceutical Sciences, vol. 67, no. 1, pp. 5760, 2005.

[9] K. Basavaiah and H. C. Prameela, "Titrimetric and spectrophotometric determination of albendazole with bromate and methyl orange," Oxidation Communications, vol. 27, no. 1, pp. 177-185, 2004.

[10] K. Basavaiah, V. Ramakrishna, and B. C. Somashekar, "Assay of albendazole using N-bromosuccinimide," The Indian Pharmacist, vol. 5, no. 53, pp. 129-136, 2006.

[11] K. Basavaiah and P. Nagegowda, "Three new methods for the assay of albendazole using N-chlorosuccinimide," Journal of
Scientific and Industrial Research, vol. 63, no. 10, pp. 835-841, 2004.

[12] K. Basavaiah, V. Ramakrishna, B. C. Somashekar, and U. R. Anilkumar, "Sensitive titrimetric and spectrophotometric methods for the assay of albendazole in pharmaceuticals using sodium periodate," Analytical Chemistry Indian Journal (TSI), vol. 2, no. 5, pp. 159-166, 2006.

[13] A. C. Tella, O. M. Olabemiwo, M. O. Salawu, and G. K. Obiyenwa, "Developing a spectrophotometric method for the estimation of Albendazole in solid and suspension forms," International Journal of Physical Sciences, vol. 5, no. 4, pp. 379382, 2010.

[14] S. C. Mandal, M. Bhattacharyya, A. K. Maity, B. K. Gupta, and S. K. Ghosal, "Determination of albendazole in tablet formulations by U.V. spectrophotometric method," Indian Drugs, vol. 29, no. 7, pp. 323-324, 1992.

[15] M. M. Fregonezi-Nery, M. M. Baracat, É. R. M. KedorHackmann, and R. M. Pinheiro, "Determination of albendazole in oral suspension," Analytical Letters, vol. 34, no. 8, pp. 12551263, 2001.

[16] O. Amit, M. Kondawar, P. Shital, S. Nazarkar, N. Manohar, and H. Narkhede, "Validated UV-spectrophotometric method for the estimation of albendazole in tablet dosage form," Journal of Pharmacy Research, vol. 3, no. 6, pp. 1355-1357, 2010.

[17] C. Soto, D. Contreras, S. Orellana, J. Yañez, and M. I. Toral, "Simultaneous determination of albendazole and praziquantel by second derivative spectrophotometry and multivariated calibration methods in veterinary pharmaceutical formulation," Analytical Sciences, vol. 26, no. 8, pp. 891-896, 2010.

[18] S. Küçükkolbaşi, B. Gündüz, and E. Kiliç, "Development of a spectrofluorimetric method for determination of albendazole in tablets," Analytical Letters, vol. 41, no. 1, pp. 104-118, 2008.

[19] G. Y. Zhao, H. Wu, S. L. Dong, and L. M. Du, "Study on the inclusion interaction of methylated- $\beta$-cyclodextrins with albendazole by spectrofluorimetry and its application," Chinese Chemical Letters, vol. 19, no. 8, pp. 951-954, 2008.

[20] A. A. Zuhri, A. I. Hussein, M. J. Musmar, and S. Yaish, "Adsorptive stripping voltammetric determination of albendazole at a hanging mercury drop electrode," Analytical Letters, vol. 32, no. 15, pp. 2965-2975, 1999.

[21] A. L. Santos, R. M. Takeuchi, M. P. Mariotti, M. F. De Oliveira, M. V. B. Zanoni, and N. R. Stradiotto, "Study of electrochemical 
oxidation and determination of albendazole using a glassy carbon-rotating disk electrode," Farmaco, vol. 60, no. 8, pp. 671674, 2005.

[22] M. F. De Oliveira and N. R. Stradiotto, "Voltammetric assay of albendazole in pharmaceutical dosage forms," Analytical Letters, vol. 34, no. 3, pp. 377-387, 2001.

[23] R. T. Sane, R. S. Samant, M. D. Joshi et al., "HPLC determination of albendazole in pharmaceuticals," Indian Drugs, vol. 26, no. 9, pp. 494-496, 1989.

[24] B. Liawruangrath and S. Liawrungrath, "HPLC method for the determination of albendazole," ACGC Chemical Research Communications, vol. 8, pp. 45-50, 1998.

[25] Y. S. R. Krishnaiah, K. Latha, R. S. Karthikeyan, and V. Satyanarayana, "HPLC method for the estimation of albendazole in pharmaceutical dosage forms," Acta Ciencia Indica, vol. 27, no. 4, p. 161, 2002.

[26] Z. Atkoşar and G. Altiokka, "The determination of albendazole by flow injection analysis method using UV-detection and HPLC method in suspensions," Journal of Liquid Chromatography and Related Technologies, vol. 29, no. 6, pp. 849-856, 2006.

[27] A. Waldia, S. Gupta, R. Issarani, and B. P. Nagori, "Validated liquid chromatographic method for simultaneous estimation of albendazole and ivermectin in tablet dosage form," Indian Journal of Chemical Technology, vol. 15, no. 6, pp. 617-620, 2008.

[28] S. J. Varghese, P. Vasanthi, and T. K. Ravi, "Simultaneous densitometric determination of ivermectin and albendazole by high-performance thin-layer chromatography," Journal of Planar Chromatography, vol. 24, no. 4, pp. 344-347, 2011.

[29] O. I. Abd El-Sattar, N. M. El-Abasawy, S. A. Abdel-Razeq, M. M. Ismail, K. A. Attia, and N. S. Rashed, "Stability indicating method for determination of albendazole and fenbendazole in the presence of their degradates," Egyptian Journal of Biomedical Sciences, vol. 18, pp. 105-109, 2005.

[30] K. Basavaiah, K. Tharpa, R. Prasad, S. G. Hiriyanna, and K. B. Vinay, "Simple, sensitive and rapid spectrophotometric determination of albendazole based on redox and complex formation using n-bromosuccinimide," Proceedings of the Indian National Science Academy, vol. 75, no. 1, pp. 1-6, 2009.

[31] C. S. P. Sastry, V. A. N. Sarma, U. V. Prasad, and C. S. R. Lakshmi, "N-bromosuccinimide as an analytical reagent for the spectrophotometric determination of benzimidazole anthelmintics," Indian Journal of Pharmaceutical Sciences, vol. 59, no. 4, pp. 161-164, 1997.

[32] S. S. Zarapkar and P. M. Deshpande, "Colorimetric determination of albendazole and its dosage forms," Indian Journal of Pharmaceutical Sciences, vol. 50, no. 5, pp. 296-297, 1988.

[33] G. Zhao, H. Li, Y. Liu, and Y. Wang, "Application of chargetransfer reaction between albendazole and chloranilic acid," Fenxi Huaxue, vol. 29, no. 4, pp. 389-400, 2001.

[34] M. S. Refat, G. G. Mohamed, and A. Fathi, "Spectrophotometric determination of albendazole drug in tablets: spectroscopic characterization of the charge-transfer solid complexes," Chinese Journal of Chemistry, vol. 29, no. 2, pp. 324-332, 2011.

[35] R. T. Sane, D. P. Gangal, R. V. Tendolkar, K. D. Ladage, and R. M. Kothurkar, "An extractive colorimetric method for the determination of albendazole from pharmaceutical preparations," Indian drugs, vol. 26, no. 11, pp. 632-635, 1989.

[36] M. S. Kamel, B. N. Barsoum, and R. Sayed, "Spectrophotometric microdetermination of anthelmintic drug in pure form and pharmaceutical formulation by ion-pair complexation," Journal of Applied Sciences Research, vol. 4, no. 10, pp. 1242-1248, 2008.
[37] C. S. P. Sastry, A. N. Sarma Varahabhatla, U. V. Prasad, and C. S. R. Lakshmi, "A note on the estimation of some benzimidazole anthelmintics in pharmaceutical preparations by ion-pair extraction method," Indian Drugs, vol. 34, no. 2, pp. 102-104, 1997.

[38] H. Abdine, F. Belal, and N. Zoman, "Simple spectrophotometric determination of cinnarizine in its dosage forms," Farmaco, vol. 57, no. 4, pp. 267-271, 2002.

[39] S. M. Al-Ghannam, "A simple spectrophotometric method for the determination of $\beta$-blockers in dosage forms," Journal of Pharmaceutical and Biomedical Analysis, vol. 40, no. 1, pp. 151156, 2006.

[40] D. H. Manjunatha, S. M. T. Shaikh, K. Harikrishna, R. Sudhirkumar, P. B. Kandagal, and J. Seetharamappa, "Simple and sensitive spectrophotometric methods for the determination of acebutolol hydrochloride in bulk sample and pharmaceutical preparations," Ecletica Quimica, vol. 33, no. 2, pp. 37-40, 2008.

[41] K. Kovács-Hadady and I. Fábián, “The determination of benzalkonium chloride in eye-drops by difference spectrophotometry," Journal of Pharmaceutical and Biomedical Analysis, vol. 16, no. 5, pp. 733-740, 1998.

[42] N. Rajendraprasad, K. Basavaiah, and K. B. Vinay, "Sensitive and selective extraction-free spectrophotometric determination of Quetiapine fumarate in pharmaceuticals using the two sulphonphthalein dyes," Journal of Preclinical and Clinical Research, vol. 4, no. 1, pp. 24-31, 2010.

[43] P. J. Ramesh, K. Basavaiah, O. Zenita Devi, and K. B. Vinay, "Simple and sensitive spectrophotometric assay of ofloxacin in pharmaceuticals based on ion-pair reaction," Chemical Industry and Chemical Engineering Quarterly, vol. 16, no. 4, pp. 353-362, 2010.

[44] M. M. El-Kerdawy, M. A. Moustafa, S. M. El-Ashry, and D. R. El-Waseef, "Spectrophotometric determination of certain phenothiazines and their dosage forms using bromophenol blue," Analytical Letters, vol. 26, no. 8, pp. 1669-1680, 1993.

[45] H. H. Abdine, "Spectrophotometric determination of cisapride using some sulfonphthalein dyes," Alex Journal of Pharmacy Science, vol. 14, pp. 75-78, 2000.

[46] A. S. Douglas and M. W. Donald, Principels of Instrumental Analysis Holt, Rinhart and Winston, New York, NY, USA, 1971.

[47] N. Erk, "Extractive spectrophotometric methods for the novel antidepressant drug in bulk and pharmaceutical dosage forms by using bromthymol blue and bromcresol green," Analytical Letters, vol. 36, no. 6, pp. 1183-1196, 2003.

[48] H. Zavis, D. Ludvik, K. Milan, S. Ladislaw, and V. Frantisck, Handbook of Organic Reagents in Inorganic Analysis, University of Aberdem, Ellis Horwood Limited, Chichester, UK, John Wiley \& Sons, New York, NY, USA, 1976, Translated by Stanislav, K., Dr. Chalmers The Series and Translation Editor.

[49] International Conference on Hormonisation of Technical Requirements for Registration of Pharmaceuticals for Human Use, ICH Harmonised Tripartite Guideline, Validation of Analytical Procedures: Text and Methodology Q2(R1), Complementary Guideline on Methodology dated 06 November 1996, incorporated in November 2005, London, UK. 

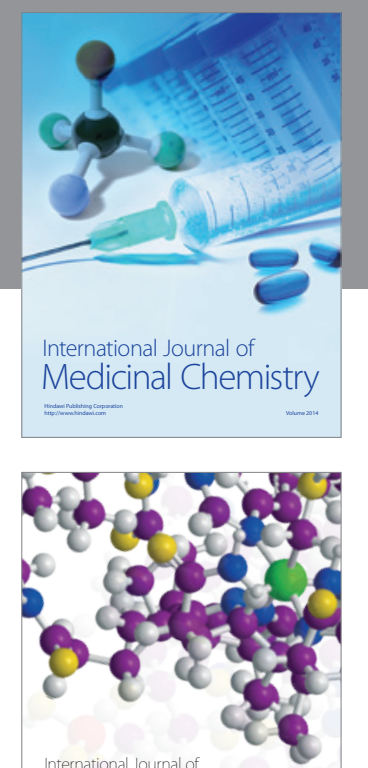

\section{Carbohydrate} Chemistry

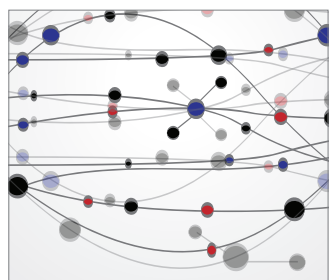

The Scientific World Journal
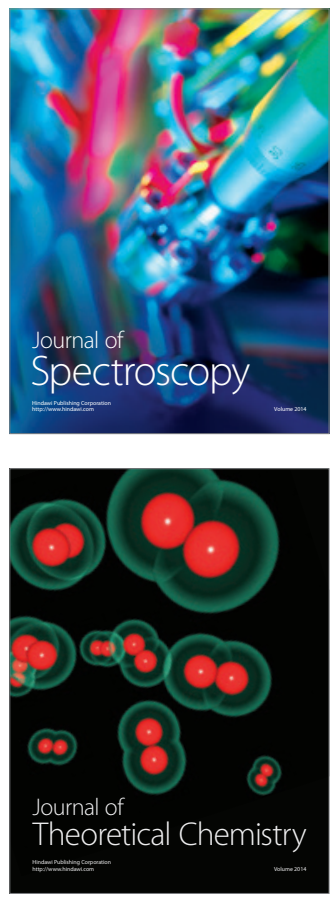
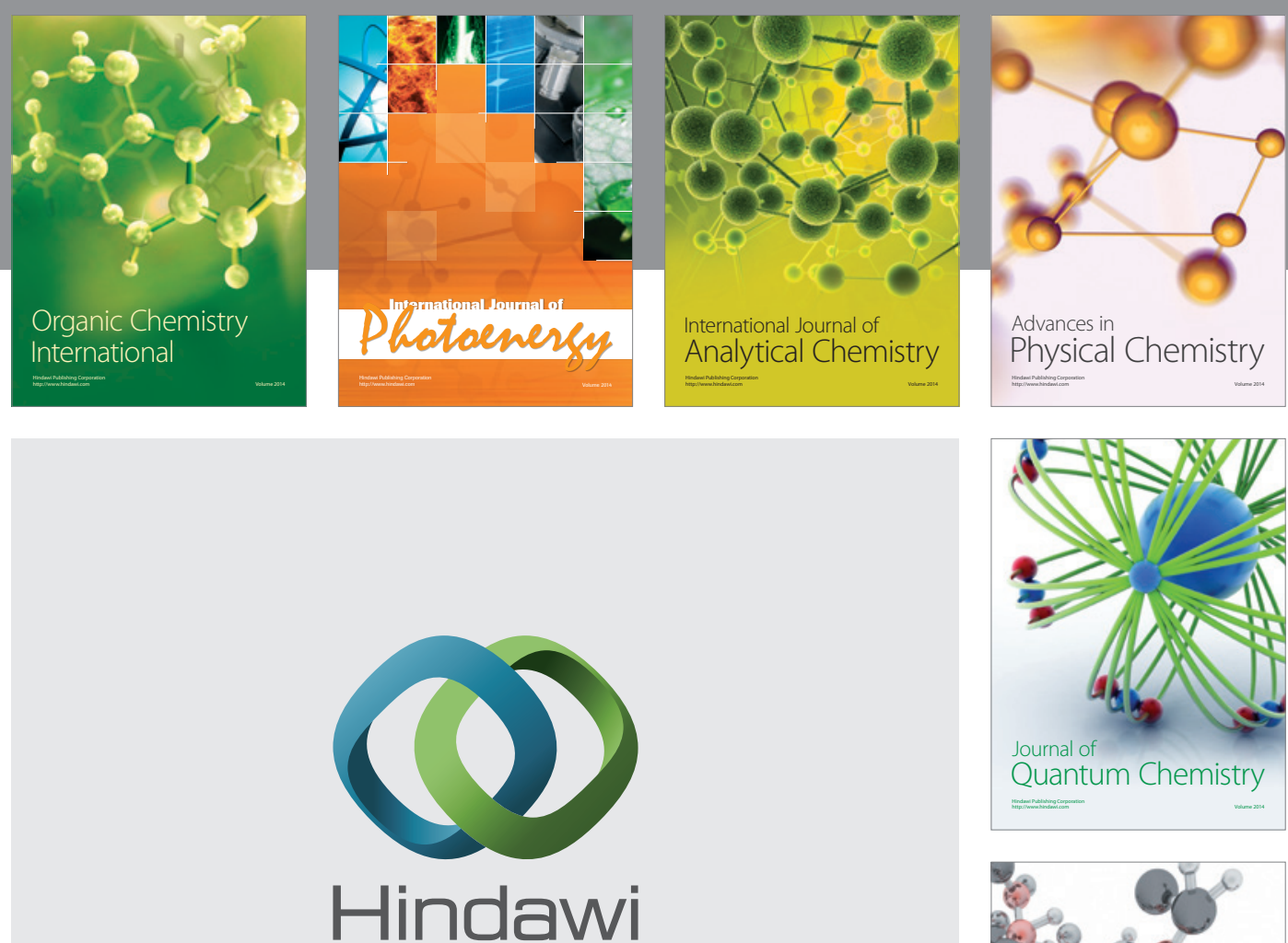

Submit your manuscripts at

http://www.hindawi.com

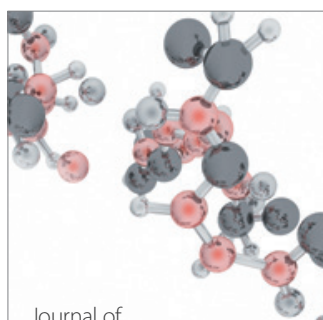

Analytical Methods

in Chemistry

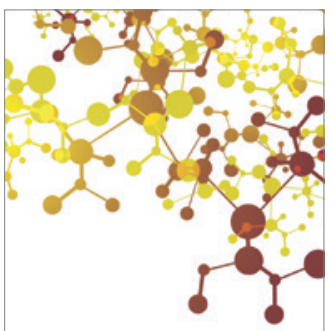

Journal of

Applied Chemistry

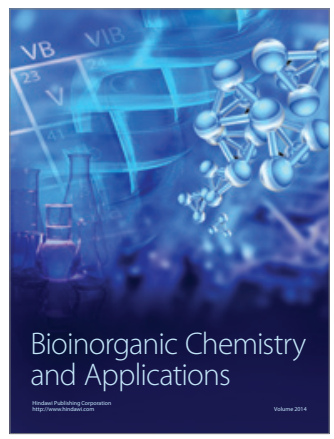

Inorganic Chemistry
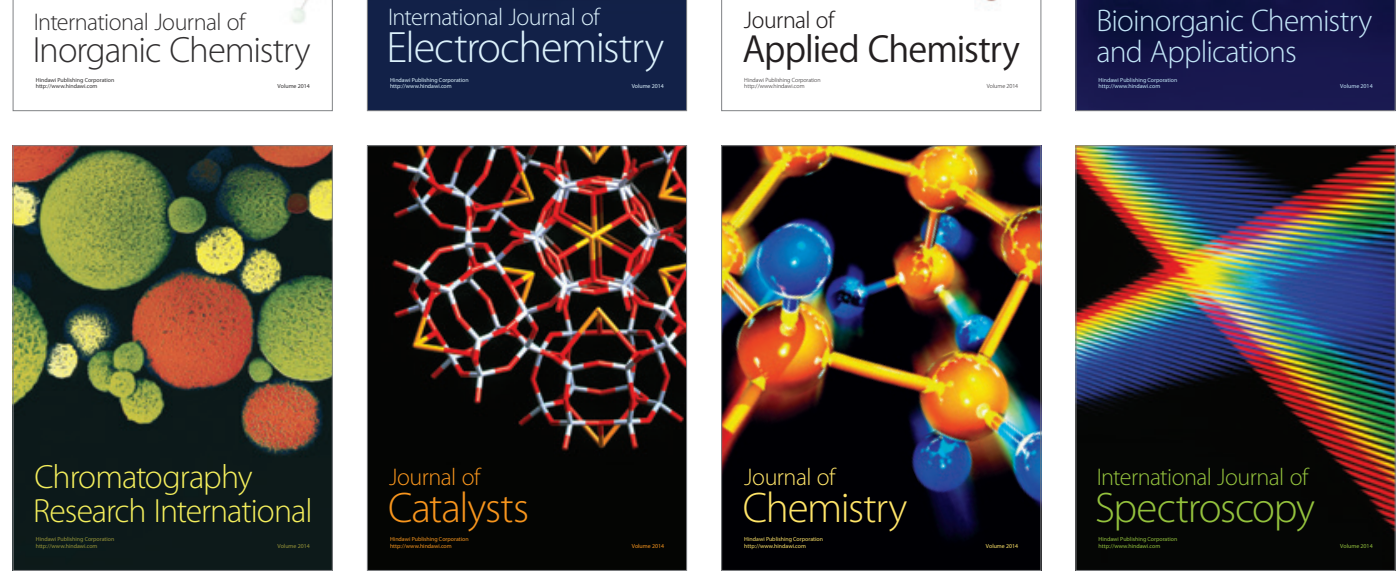